\title{
PERAN KOMITMEN AFEKTIF DALAM MEMEDIASI LEARNING ORIENTATION DAN MODAL SOSIAL TERHADAP KINERJA SUMBER DAYA MANUSIA
}

\author{
Zaenudin \\ An Nisa Nuur Prasetyaninghayu \\ Universitas Islam Sultan Agung Semarang \\ annisanuur93@gmail.com
}

\begin{abstract}
This study aims to determine and analyze the influence of learning orientation and social capital on human resource performance with affective commitment as an intervening variable at PT. SAl Apparel Industries Semarang. Population in this research is all employees of production of PT. SAl Apparel Industries Semarang as many as 3.100 people, with a sample size of 97 respondents. The sampling technique is Proportional Random Sampling. The analytical tool is the path of analysis, where previously tested the validity and reliability as well as the classical assumption test. The result showed that learning orientation and social capital proved to have positive and significant impact on affective commitment and human resource performance. Affective commitment has a positive and significant effect on human resource performance. Affective commitment can be an intervening variable between learning orientation towards human resource performance, meaning higher learning orientation, it will increasingly make the employee able to adjust themselves between the system with the work environment so that it will increase the affective commitment of employees in achieving maximum performance. Affective can be a variable intervening between social capital to human resource performance, it can be interpreted that the height of social capital, the more the formation of sense of togetherness, solidarity, and also the responsibility of common progress in supporting employees affective commitment, which will certainly impact on the high performance of employees maximum.
\end{abstract}

Keywords: Learning orientation, social capital, affective commitment and human resource
performance PENDAHULUAN

Kinerja (performance) adalah hasil kerja yang dicapai seseorang, baik secara kualitas maupun kuantitas dalam melaksanakan kesesuaian tugas (Mangkunegara, 2012). Kinerja

dapat maksimal jika adanya kerjasama diantara karyawan dan manajemen dalam berbagai kelompok di organisasi tersebut, sehingga mampu memberikan manfaat yang dirasakan bersama. Bentuk interaksi atau kerjasama tersebut didasarkan dengan adanya kepercayaan sesama anggota yang mengakar dalam suatu budaya organisasi dan etika sosial (modal sosial). Untuk itulah modal sosial berperan sebagai unsur perekat dalam meningkatkan kinerja karyawan dalam melaksanakan visi dan misi perusahaan untuk mencapai tujuan organisasi. Hal ini sesuai pernyataan Akdere (2005) dalam Yosna (2013) bahwa eksistensi modal sosial karyawan menjadi penting karena mempengaruhi kinerja karyawan yang pada gilirannya mempengaruhi kinerja organisasi.

PT. SAI Apparel Industries Semarang 
merupakan perusahaan manufaktur yang proses produksinya bergerak dalam industri garmen. Dalam pencapaian kinerja yang maksimal, maka peran karyawan merupakan elemen yang cukup dominan dalam rangka meningkatkan dan mengembangkan tugas-tugas khususnya guna memperoleh hasil yang maksimal dari segi kualitas dan kuantitas. Dalam menetapkan kinerja yang maksimal, maka pihak manajemen menetapkan standar dalam proses produksi, yaitu memberikan target kepada karyawan bagian produksi untuk memperkecil tingkat kerusakan, yaitu dengan ketentuan sebesar $2,5 \%$ dari produksi yang dihasilkan. Hal yang melatarbelakangi permasalahan dalam upaya memperkecil tingkat kerusakan produk, maka kualitas sumber daya justru kurang mendapat banyak perhatian dari pihak manajemen. Dampak dengan kurangnya perhatian dari pihak manajemen mempengaruhi dengan produk yang dihasilkan.

Penelitian tentang kinerja sumber daya manusia pernah dilakukan oleh beberapa peneliti, seperti yang dilakukan pada Widodo (2009) yang menunjukkan bahwa orientasi belajar mempunyai pengaruh positif terhadap kinerja organisasi. Hasil penelitian Makrufah (2011) dan Ressya (2014) menjelaskan bahwa pembelajaran organisasi mempunyai pengaruh positif terhadap kinerja karyawan. Akan tetapi pada penelitian Zainun (2014) dan Senge (2012) justru terjadi sebaliknya bahwa learning organization tidak berpengaruh terhadap kinerja karyawan.

Hasil penelitian yang dilakukan Stam dan Elfring (2008) dan Wahyuningrum (2013) menunjukkan bahwa modal sosial memiliki pengaruh terhadap kinerja karyawan. Begitu halnya dengan penelitian yang dilakukan Khoirini dan Kartika (2014) bahwa modal sosial mempunyai pengaruh terhadap kinerja karyawan, sedangkan hasil penelitian Rapih dan Martono (2016) bahwa modal sosial justru tidak berpengaruh terhadap kinerja karyawan. Hasil penelitian
Widodo (2009) dan Armanu dan Mandayanti (2011) menunjukkan bahwa komitmen afektif berpengaruh positif terhadap kinerja pegawai, sedangkan penelitian Muchiri (2012), Andrawina, dkk (2008) dan Husammi (2008) menunjukkan bahwa komitmen afektif berpengaruh negatif terhadap kinerja karyawan.

Berdasarkan hasil penelitian tersebut menunjukkan kontradiksi antara peneliti satu dengan lainnya, terutama pada variabel learning orientation, modal sosial dan komitmen afektif. Untuk itu dalam penelitian ini akan menguji kembali dengan mengacu pada penelitian terdahulu yang hasilnya masih inkonsisten. Dengan terjadinya kontradiksi tersebut, maka kinerja karyawan dapat dipengaruhi karena faktor learning orientation, modal sosial dan komitmen afektif.

Orientasi belajar merupakan proses belajar dari karyawan sebagai suatu pengaruh penyesuaian diri yang mempengaruhi hubungan antara suatu system dengan lingkungan luarnya. Dengan adanya proses belajar, maka membuat karyawan dapat bertindak melalui berbagai cara sesuai dengan lingkungan kerja dalam upaya meningkatkan kinerja yang dihasilkan (Fiere, 1985). Orientasi belajar yang dilakukan karyawan lebih menunjuk pada wawasan atau usaha-usaha menemukan hal-hal baru dan pandangan ke depan dalam pencapaian kinerja yang maksimal (Nomaka dan Takeuchi, 1995) dalam Widodo (2009).

Modal sosial merupakan suatu komitmen dari setiap individu untuk saling terbuka, saling percaya, memberikan kewenangan bagi setiap orang yang dipilihnya untuk berperan sesuai dengan tanggungjawabnya. Dengan demikian semakin tinggi modal sosial, maka akan semakin terbentuknya rasa kebersamaan, kesetiakawanan, dan sekaligus tanggungjawab akan kemajuan bersama sehingga akan semakin meningkatkan kinerja SDM. Hal ini sesuai pernyataan Akdere (2005) dalam Yosna (2013) bahwa eksistensi modal sosial 
menjadi penting karena mempengaruhi kinerja karyawan yang pada gilirannya akan mempengaruhi kinerja organisasi.

Komitmen afektif adalah kesediaan individu untuk bertahan dalam organisasi yang ditandai dengan adanya keterikatan emosional dengan organisasi, identifikasi terhadap nilai dan tujuan organisasi, serta keterlibatan dalam organisasi (Christa, 2013). Pemilihan terhadap komitmen afektif disebabkan karena untuk meningkatkan kinerja SDM sangat dibutuhkan keterikatan dalam diri karyawan secara emosional atau psikologis dalam memajukan perusahaan, seperti dukungan moral dan menerima nilai yang ada di dalam organisasi serta tekad dari dalam diri untuk mengabdi kepada organisasi. Selain itu, komitmen afektif juga lebih bernilai bagi perusahaan dibandingkan kedua tipe komitmen kontinuen dan normatif, karena sudah melibatkan faktor emosional sehingga karyawan dengan komitmen afektif akan bekerja dengan perasaan senang dan menikmati perannya dalam perusahaan (Mowday, et,al 1979 seperti dikutip Armanu dan Mandayanti, 2011).

Berdasarkan permasalahan tersebut, maka dapat dirumuskan yaitu bagaimana upaya yang dilakukan pihak manajemen perusahaan dalam meningkatkan kinerja SDM, sehingga pertanyaan penelitiannya adalah bagaimana pengaruh learning orientation dan modal social terhadap kinerja SDM dengan komitmen afektif sebagai variable intervening pada PT. SAI Apparel Industries Semarang?

\section{KAJIAN PUSTAKA \\ Kinerja SDM}

Dessler (2009) mendefinisikan kinerja sebagai perbandingan antara hasil kerja yang secara nyata dengan standar kerja yang ditetapkan. Dengan demikian kinerja lebih memfokuskan pada hasil kerjanya. Penilaian kinerja bertujuan memberikan umpan balik kepada karyawan dengan tujuan memotivasi orang tersebut untuk menghilangkan kemerosotan kinerja atau berkinerja lebih tinggi lagi.

Handoko (2012) mendefinisikan kinerja sebagai keadaan emosional yang menyenangkan atau tidak menyenangkan. Hal ini akan tampak dari sikap positif karyawan terhadap segala sesuatu yang dihadapi di lingkungan kerja. Kinerja berhubungan erat dengan sikap dari karyawan terhadap pekerjaannya, situasi kerja, kerja sama diantara karyawan dan manajemen dan antar sesama keduanya. Hal ini menunjukkan bahwa kinerja sebagai hasil interaksi manusia dengan lingkungan kerja.

Berdasarkan definisi tersebut dapat disimpulkan bahwa kinerja sumber daya manusia merupakan hasil kerja seseorang baik secara kualitas maupun kuantitas berdasarkan tanggung jawab yang telah dibebankan kepada karyawan. Dengan demikian tanpa sumber daya manusia, suatu organisasi tidak mungkin berjalan. Hal tersebut karena sumber daya manusia merupakan penggerak dan pengelola faktor produksi lainnya untuk mencapai tujuan organisasi.

Kinerja karyawan mengacu pada prestasi kerja yang diukur berdasarkan standar atau kriteria yang telah ditetapkan perusahaan. Di dalam melakukan pengukuran kinerja (performance measurement), organisasi hendaknya dapat menentukan aspek aspek apa saja yang dapat menjadi topik pengukurannya. Miner (2002) menetapkan komponen variabel pengukuran kinerja ke dalam tiga kelompok besar, yaitu: (1) berkaitan dengan karakteristik kualitas kerja pegawai; (2) berkaitan dengan kuantitas kerja pegawai; dan (3) berkaitan dengan kemampuan bekerjasama dengan pegawai lainnya.

Menurut Riduwan (2009) bahwa indikator kinerja dapat dinilai dari kemampuan untuk mempunyai inisiatif mencari langkah yang terbaik, menguasai Job Description, hasil yang dicapai, tingkat kemampuan kerjasama, ketelitian, tingkat kesesuaian tugas dengan perintah, tingkat kualitas hasil 
kerja, tingkat ketepatan penyelesaian kerja dan tingkat kuantitas hasil kerja.

Miner (Widjajanti dan Widodo, 2014) menjelaskan bahwa komponen kinerja dapat ditentukan oleh tiga kelompok besar, yaitu: (1) berkaitan dengan karakteristik kualitas kerja pegawai; (2) berkaitan dengan kuantitas kerja pegawai; dan (3) berkaitan dengan kemampuan bekerjasama dengan pegawai lainnya. Sedangkan Mathis dan Jackson (2006) menyebutkan, ada beberapa elemen dalam pengukuran kinerja, diantaranya dapat dilihat dari kuantitas dari hasil yang dicapai, kualitas dari hasil, ketepatan waktu dari hasil, kehadiran serta kemampuan untuk bekerjasama.

\section{Learning Orientation}

Friere (1977) dalam Widodo (2009) mendefinisikan orientasi belajar sebagai suatu pengaruh penyesuaian diri yang mempengaruhi hubungan antara suatu sistem dengan lingkungan luarnya. Proses belajar membuat orang dapat bertindak melalui berbagai cara sesuai dengan lingkungan sekelilingnya dengan berbagai cara aksi tindakan individu sendiri yang memungkinkan untuk belajar. Menurut Watkins and Marsick (2003) dalam Uniati (2014) orientasi belajar pada organisasi dapat diartikan sebagai sebuah sistem integratif yang diterapkan di tempat kerja dan lingkungan untuk mendukung proses belajar.

Studi Horwitz, (1999) berpendapat orientasi pada pembelajaran merupakan investasi jangka panjang. Begitu juga dalam penelitian Schwandt dan Marquardt (2000) bahwa organisasi pembelajaran dapat bertahan dalam jangka panjang dan cepat merespon tantangan yang ada. Oleh sebab itu sudah sewajarnya mendapat perhatian dan prioritas dari perusahaan sedini mungkin. Hal ini dapat diartikan bahwa karyawan harus mengedepankan proses belajar pada dirinya dan implikasi hasil atas proses pembelajaran tersebut dengan meningkatkan kemampuan manajerial pada diri setiap karyawan. Dengan demikian orientasi pembelajaran lebih memastikan adanya suatu perubahan yang positif yang lebih merujuk pada peningkatan baik dari sisi karyawan maupun organisasi (Ellis dan Raymond, 1993 dalam Widodo, 2009).

Menurut Senge (1990) menjelaskan bahwa organisasi pembelajaran merupakan suatu organisasi dimana setiap anggotanya secara berkelanjutan meningkatkan atau memperluas kemampuannya untuk menciptakan hasil yang benar-benar mereka inginkan, dengan pola berfikir yang baru dan meluas, bebas beraspirasi bersama untuk memahami segala sesuatu.

Dengan demikian proses belajar lebih menunjuk pada wawasan dalam diri individu terhadap usaha yang dilakukan dalam menemukan hal-hal baru dalam menemukan pandangan ke depan. Fiol dan Lyles (1985) dalam Widodo (2009) menjelaskan bahwa proses belajar organisasi terutamanya lebih berorientasi pada dimensi kognitif dan keperilakuan, terdapat 4 hal yang ada di dalam konteks, antara lain budaya, strategi, struktur dan lingkungan. Pertama, budaya sebagai keyakinan, norma, ideologi yang saling dimiliki dalam mempengaruhi tindakan. Kedua, strategi sebagai sikap organisasidalammenghadapi pasar. Konteks ketiga adalah struktur, yaitu pembuatan keputusan, sentralisasi/desentralisasi, sifat sederhana/sifat majemuk dll. Keempat adalah lingkungan yang bersifat internal dan eksternal serta mencurahkan perhatian pada tegangan antara ketidakberubahan dan perubahan serta berbagai intensitas stres yang terjadi pada organisasi.

Pembelajaran berkesinambungan merupakan inti dari organisasi pembelajaran. Selain itu orientasi belajar harus melihat ke dalam dirinya sendiri, dengan kata lain tidak ada pembelajaran instan yang bisa diterapkan sama pada semua pihak. Kekuatan organisasi pembelajaran lebih kepada kemampuan organisasi untuk menilai siapa dirinya, siapa orang-orang didalamnya yang selanjutnya digunakan 
sebagai sumber analisa dalam menentukan model pembelajaran yang sesuai dengan ciri khas suatu organisasi. Untuk menjawab tantangan itu tentu saja perlu kerjasama antara organisasi dengan individu di dalamnya, kepekaan mengenai visi dan misi, kemampuan mengetahui harapanharapan karyawan, serta kemampuan untuk merubah sikap dan perilaku kerja karyawan. Diharapkan dengan kondisi saat ini yang penuh persaingan, dimana yang siap akan tetap maju dan yang tidak siap akan tertinggal maka karyawan dapat termotivasi untuk selalu berbenah, baik sikap mental maupun ketrampilannya.

Menurut Mikkelsen, et. al (2000) dalam Mas'ud (2004) bahwa pembelajaran organisasi dapat diukur antara melalui keterlibatan atasan, waktu, bertanggung jawab, kemudahan bantuan dari tim, kesempatan berdiskusi, perlakuan secara adil dan mau berusaha dengan baik. Sedangkan menurut Kumar (1994) dalam Widodo (2009) menjelaskan bahwa orientasi belajar dapat diukur dengan indikator mengetahui hal-hal baru, melakukan training, umpan balik dan pengembangan secara kontinue.

\section{Modal Sosial}

Cohen dan Prusak (2001) memberikan pengertian modal sosial sebagai kesediaan melakukan hubungan aktif antara seseorang yang didasarkan kepercayaan, kerjasama yang saling menguntungkan, berbagai nilai dan perilaku yang mengikat setiap anggota jaringan dan kemsyarakatan juga memungkinkan kerjasama.

Modal sosial (sosial capital) sebagai struktur hubungan antar individu-individu yang memungkinkan mereka menciptakan nilai-nilai baru (Coleman, 2005). Sedangkan Putnam dalam Lubis (2011) mendefinisikan modal sosial sebagai organisasi sosial dengan jaringan sosial, norma-norma dan kepercayaan sosial yang dapat menjembatani terciptanya kerjasama dalam komunitas sehingga terjalin kerjasama yang saling menguntungkan. Modal sosial merupakan suatu komitmen dari setiap individu untuk saling terbuka, saling percaya, memberikan kewenangan bagi setiap orang yang dipilihnya untuk berperan sesuai dengan tanggungjawabnya. Sarana ini menghasilkan rasa kebersamaan, kesetiakawanan, dan sekaligus tanggungjawab akan kemajuan bersama.

Pemahaman modal sosial diharapkan akan meningkatkan kinerja suatu organisasi. Di sisi bisnis bahwa melalui modal sosial akan membangun dan mendorong karyawan lebih menarik berbisnis, dan dapat mengeksplorasi kesempatan dan kemungkinan terbaik yang didapatkan jaringan kerja. Bagi organisasi, modal sosial dapat menjaga hubungan baik, baik dari kuantitas dan kualitas dari norma dari interaksi yang memungkinkan seseorang mengkoordinir tindakan untuk mencapai tujuan yang diinginkan. Putnam (1995) dalam Widodo (2009) menjelaskan bahwa modal sosial sebagai fitur organisasi sosial seperti jaringan kerja, kepercayaan sosial yang memfasilitasi koordinasi dan kerja untuk mendapatkan keuntungan.

Terbentuknya modal sosial sangat bergantung pada mutu sumber daya manusianya. Dalam prakteknya bisa jadi mutu mereka berbeda-beda. Baik dilihat dari segi budaya, latar belakang sosial ekonomi keluarga, pendidikan, ketrampilan, kecerdasan (intelektual, emosional, dan spiritual), kepemimpinan, dan pengalaman kerja. Karena modal sosial berperan sebagai unsur perekat para karyawan dalam melaksanakan visi dan misi organisasi untuk mencapai tujuan organisasi maka dibutuhkan sumber daya manusia yang bermutu.

Indikator yang dapat dijadikan ukuran modal sosial antara lain (Spellerber, 1997; Suharto, 2009) antara lain melalui perasaan memiliki atau sebaliknya, perasaan alienasi, sistem kepercayaan dan ideologi, nilai-nilai dan tujuan-tujuan, sikap-sikap terhadap anggota lain dalam masyarakat, persepsi 
mengenai akses terhadap pelayanan, sumber dan fasilitas (misalnya pekerjaan, pendapatan, pendidikan, perumahan, kesehatan, transportasi, jaminan sosial), opini mengenai kinerja pemerintah yang telah dilakukan terdahulu, keyakinan dalam lembaga-lembaga masyarakat dan orangorang pada umumnya, tingkat kepercayaan, kepuasaan dalam hidup dan bidang-bidang kemasyarakatan lainnya, serta harapanharapan yang ingin dicapai di masa depan. Sedangkan Huselid, et, al (1997) (dikutip dalam Widodo, 2009) mengukur modal sosial (sosial capital) dapat diukur antara lain dengan indikator sharing informasi, interaksi dan tukar ide, optimalisasi pengetahuan, dan kualitas jejaring.

\section{Komitmen Afektif}

Menurut Greenberg (1997) (dikutip dalam Indriasari, 2013) menjelaskan bahwa komitmen afektif dapat diartikan sebagai the strength of a person's desire to work for organizationl because he or she agrees with it and wants to do so. Komitmen afektif dapat diartikan sebagai kekuatan seseorang untuk bekerja di dalam sebuah organisasi, karena mereka menyetujui dan berkeinginan untuk melakukan pekerjaan tersebut (Muchiri, 2012).

Komitmen afektif berkaitan dengan emosional, identifikasi dan keterlibatan individu di dalam suatu organisasi, anggota yang mempunyai komitmen ini mempunyai keterikatan emosional terhadap organisasi yang tercermin melalui keterlibatan dan perasaan senang serta menikmati peranannya dalam organisasi. Dengan demikian komitmen afektif dinilai lebih tinggi daripada komitmen normatif dan kontinuan, sedangkan komitmen normatif dinilai lebih tinggi daripada komitmen kontinuan (komitmen rasional) (Nurtjahjanti, 2013). Oleh karena itu, dalam konteks penelitian ini dapat dikatakan bahwa karyawan yang mempunyai komitmen afektif akan lebih bernilai bagi perusahaan dibandingkan kedua tipe komitmen yang lain karena sudah melibatkan faktor emosional sehingga karyawan dengan komitmen afektif akan bekerja dengan perasaan senang dan menikmati perannya dalam perusahaan.

Karyawan dengan komitmen afektif benar-benar ingin menjadi karyawan di perusahaan yang bersangkutan sehingga memiliki keinginan untuk menggunakan usaha optimal demi tercapainya tujuan perusahaan. Karyawan dengan komitmen kontinuan cenderung melakukan tugasnya dikarenakan menghindari kerugian finansial dan kerugian lain, sehingga hanya melakukan usaha yang tidak optimal. Menurut Meyer, Allen dan Smith (1993) dalam Sabir, dkk (2011) menjelaskan bahwa untuk menilai komitmen afektif dapat diukur antara lain dengan menghabiskan sisa karir, bangga terhadap organisasi, terikat dengan organisasi, terikat secara emosional, memiliki arti yang besar dan mempunyai rasa yang kuat terhadap organisasi..

\section{Hubungan Antar Variabel \\ Pengaruh Learning Orientation terhadap Komitmen Afektif}

Joo dan Lim (2009) menjelaskan bahwa karyawan secara psikologis dan emosional lebih terikat pada organisasi yang memberikan kesempatan belajar bersama yang berkelanjutan. Dengan memberikan kesempatan belajar, maka akan menumbuhkan rasa memiliki sehingga dapat mengimplementasikan tujuan organisasi secara bersama-sama dalam learning orientation, dimana karyawan akan diberi pelatihan, pengembangan ketrampilan dalam memajukan perushaan.

Wang (2007) menegaskan bahwa menciptakan dan mendorong budaya pembelajaran organisasi adalah mekanisme mendasar untuk memupuk kepuasan kerja, komitmen organisasi, dan memastikan angkatan kerja yang sehat dan stabil dalam jangka panjang. Ini berarti bahwa pembelajaran organisasi dapat meningkatkan tingkat komitmen organisasi di antara karyawan dan dapat menghasilkan 
hasil kerja yang positif.

Hasil penelitian

menunjukan bahwa orientasi belajar terbukti berpengaruh terhadap komitmen karyawan. Hal tersebut mengindikasikan bahwa untuk meningkatkan komitmen karyawan dibangun oleh orientasi belajar. Hasil tersebut mendukung studi Song (2008) dalam Widodo (2010), bahwa orientasi pembelajaran berarti memastikan adanya sebuah perubahan positif baik dari peningkatan karyawan maupun organisasi. Karyawan terhadap orientasi belajar akan menciptakan dan menularkan antusias yang sama pada rekan-rekan dan komitmen organisasi. Hasil penelitian Shanker (2013) menunjukkan adanya korelasi kuat antara pembelajaran organisasi dan komitmen organisasi lebih khususnya pada komitmen afektif (Shanker, 2013), sehingga dapat dirumuskan hipotesis sebagai berikut :

$\mathrm{H}_{1}$ : Learning Orientation berpengaruh positif terhadap Komitmen Afektif

\section{Pengaruh Modal Sosial terhadap Komitmen Afektif}

Modal sosial adalah produk dari hubungan dan interaksi positif antara individu di perusahaan. Modal sosial membawa manfaat dari hubungan kolaboratif dan sinergis yang efisien. Karyawan yang memiliki sosial capital yang kuat akan lebih mudah berinteraksi dengan rekan kerja dan menjalin hubungan serta jaringan yang baik dengan seluruh anggota organisasi. Modal ini sangat penting agar karyawan dapat merasakan suasana yang mendukung meningkatnya komitmen. Inilah dasar modal sosial sebagai modal interaksi dan hubungan individu di tempat kerja, yang membuat orang bekerja sama dan meningkatkan kapasitas untuk inovasi, komitmen, fleksibilitas dan adaptasi pengetahuan dan pengayaan belajar (Beyerlen et al., 2005).

Vincent Rousseau dan Caroline Aube (2010) menjelaskan bahwa dukungan sosial yang termasuk komponen sosial capital dapat meningkatkan kenyamanan karyawan dalam organisasi dengan memenuhi kebutuhan untuk harga diri, persetujuan, dan afiliasi. Karyawan yang mendapatkan dukungan sosial dalam organisasi serta memiliki pengalaman kerja yang memuaskan dan ikatan secara emosional akan memiliki komitmen yang kuat dan berdampak pada kinerjanya yang optimal serta mengembangkannya dalam organisasi yang mempekerjakan mereka.

Penelitian yang dilakukan Naseer dan Mahmod (2015) menunjukkan bahwa peningkatan sosial capital mempengaruhi komitmen afektif yang ada di dalam diri karyawan. Hasil ini konsisten dengan hasil penelitian lain seperti (Atak \& Ramazan, 2010, Ellinger et al, 2013), yang menegaskan adanya pengaruh positif nilai dan standar sosial terhadap komitmen organisasional., sehingga dapat dirumuskan hipotesis:

$\mathrm{H}_{2}$ : Modal Sosial berpengaruh positif terhadap Komitmen Afektif

\section{Pengaruh Learning Orientation terhadap Kinerja SDM}

Orientasi belajar dilakukan untuk menemukan hal-hal baru dan pandangan ke depan dalam pencapaian kinerja secara maksimal. Hal ini sesuai pernyataan Walle an Cummings (1997) dalam Widodo (2009) bahwa orientasi pembelajaran digunakan sebagai strategi pengendalian diri pada organisasi karena dapat membentuk ketrampilan dan kemampuan sumber daya manusia serta memiliki pengetahuan yang dapat meningkatkan kinerja. Hal serupa juga disampaikan oleh Weitz dan Kumar (1994) bahwa orientasi pembelajaran mampu mendorong sumber daya manusia untuk lebih bekerja keras karena diharapkan dapat menikmati pekerjaan yang dilakukan sehingga kinerja yang dicapainya tinggi.

Peneliti lain juga menemukan bahwa ada dampak positif dari pelatihan dan pengembangan sebagai bagian dari pendekatan orientasi pembelajaran dengan nilai pembelajaran dalam mencapai tujuan profesional (Shafiq, Zia-ur-Rehman \& 
Rashid, 2013). Hasil penelitian yang dilakukan Widodo (2009) menunjukkan bahwa orientasi belajar mempunyai pengaruh positif terhadap kinerja sumber daya manusia, sehingga dapat dirumuskan hipotesis sebagai berikut:

$\mathrm{H}_{3}$ : Learning Orientation berpengaruh positif terhadap Kinerja SDM

\section{Pengaruh Modal Sosial terhadap Kinerja SDM}

Modal sosial sebagai serangkaian nilainilai atau norma-norma informal yang dimiliki bersama diantara para anggota suatu kelompok yang memungkinkan terjalinnya kerjasama di antara mereka (Fukuyama (1995). Nahapiet dan Ghoshal (1998) juga menyatakan bahwa modal sosial relasional terbentuk dari kesamaan sistem keyakinan yang terdapat dalam modal sosial kognitif dan kemampuan masing-masing aktor dalam memaknai pengalaman yang dihadapi bersama.

Konsep modal sosial (sosial capital) sedang berkembang saat ini didasari pemahaman bahwa modal sosial akan berpengaruh pada kinerja. Hal ini didukung beberapa riset yang menunjukkan adanya pengaruh modal sosial terhadap kinerja (Belliveau, O'Reilly, \& Wade, 1996). Organisasi-organisasi mulai menyadari pentingnya interaksi serta hubungan yang baik antar karyawan di dalam pekerjaan. Eksistensi modal sosial karyawan menjadi penting karena mempengaruhi kinjerja karyawan yang pada gilirannya mempengaruhi kinerja organisasi (Akdere, 2005 seperti dikutip dalam Yosna, 2013). Hal inilah yang kemudian mendasari mengapa kemudian perusahaan perlu mengadopsi penilaian kinerja dengan melihat faktor modal sosial yang dimiliki oleh karyawan sebagai aktor utama didalam penyelenggaraan perusahaan.

Penelitian tentang modal sosial terhadap kinerja karyawan telah banyak dilakukan seperti yang dilakukan Stam dan Elfring (2008), Wahyuningrum (2013) dan Khoirini dan Kartika (2014) yang menyatakan bahwa modal sosial memiliki pengaruh langsung terhadap kinerja karyawan, sehingga dirumuskan hipotesis :

$\mathrm{H}_{4}$ : Modal Sosial berpengaruh positif terhadap Kinerja SDM

\section{Pengaruh Komitmen Afektif terhadap Kinerja SDM}

Komitmen yang kuat dalam diri karyawan akan menyebabkan individu berusaha keras dalam mencapai tujuan organisasi. Tingginya komitmen karyawan terhadap organisasi disebabkan karena adanya interaksi atau kerja sama yang didasarkan kepercayaan yang tinggi dari karyawan terhadap organisasi. Semakin tinggi komitmen karyawan terhadap organisasi maka tentu membawa dampak perubahan yang besar bagi karyawan untuk memberikan yang terbaik bagi perusahaan yang didasarkan adanya kepercayaan sesama anggota organisasi..

Perusahaan dapat berkembang dengan pesat karena adanya komitmen dari para karyawan yang tinggi terhadap perusahaan. Karyawan yang memiliki tingkat komitmen yang tinggi terhadap perusahaan akan memiliki pandangan yang positif dalam melakukan kerjasama sesama anggota yang mengakar pada budaya organisasi dan etika sosial (Robbins, 2009). Komitmen organisasi merupakan dorongan dari dalam diri individu untuk berbuat sesuatu agar dapat menunjang keberhasilan organisasi sesuai dengan tujuan dan lebih mengutamakan kepentingan organisasi. Komitmen organisasi yang kuat dalam diri individu akan menyebabkan individu berusaha keras mencapai tujuan organisasi, yaitu meningkatkan kinerja pegawai sesuai dengan tujuan dan kepentingan organisasi. Semakin tinggi komitmen pegawai terhadap organisasi, maka akan semakin tinggi pula kinerja pegawai dalam menyelesaikan pekerjaan secara optimal. Hal ini sesuai pernyataan Mowday et al. (1979) seperti dikutip Armanu dan Mandayanti (2011) 
bahwa komitmen organisasi menunjukkan keyakinan dan dukungan yang kuat terhadap nilai dan sasaran (goal) yang ingin dicapai oleh organisasi, yaitu meningkatkan kinerja pegawai.

Pegawai yang memiliki tingkat komitmen organisasi yang tinggi, akan memiliki pandangan yang positif dan lebih berusaha berbuat yang terbaik demi kepentingan organisasi. Suatu organisasi dapat berkembang dengan pesat karena

\section{Model Empirik Penelitian}

Berdasarkan kajian pustaka terhadap keterikatan antar variable penelitian dapat dijelaskan dalam kerangka pemikiran teoritis berikut ini :

\section{METODE PENELITIAN}

\section{Populasi dan Sampel}

seluruh karyawan bagian produksi PT. SAI Apparel Industries Semarang sebanyak 3.100 orang, dengan jumlah sampel 97

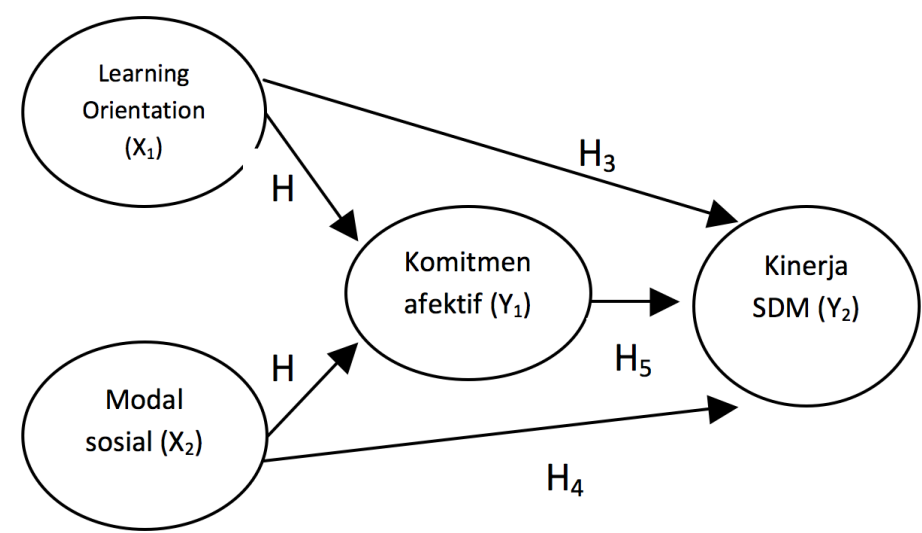

adanya komitmen dari para pegawai yang tinggi terhadap organisasi. Hasil penelitian Armanu dan Mandayanti (2011) bahw komitmen afektif berpengarih terhadap kinerja karyawan, dengan arah positif. Hasil penelitan Syain (2013) dan Tobing (2009) juga menunjukkan bahwa komitmen afektif berpengaruh positif terhadap kinerja karyawan. Atas dasar argumentasi dan didukung penelitian terdahulu tersebut, maka dapat dirumuskan hipotesis sebagai berikut :

$\mathrm{H}_{5}$ : Komitmen Afektif berpengaruh terhadap Kinerja SDM responden. Agar dapat mewakili pada msingmasing bagian, maka teknik pengambilan sampel yang digunakan adalah Proportional Random Sampling.

\section{Metode Analisis Data}

Metode analisa data dilakukan dengan uji analisis kuantitatif dengan alat analisis adalah Path analisis dimana sebelumnya dilakukan uji validitas dan reliabilitas serta uji persyaratan asumsi klasik. Adapun persamaan regresinya dapat ditulis sebagai berikut:

$$
Y_{1}: \beta_{1} X_{1}+\beta_{2} X_{2}+e_{1}
$$

\section{Path Analysis}

Tabel 1. Hasil Persamaan Regresi

\begin{tabular}{|c|c|c|c|c|}
\hline Variabel & $\mathrm{B}$ & $\mathrm{t}$ & Sig & Ket. \\
\hline $\mathrm{X}_{1} \rightarrow \mathrm{Y}_{1}$ & 0,506 & 5,905 & 0,000 & $\begin{array}{c}\text { Ha diterima } \\
\text { Ha diterima }\end{array}$ \\
$\mathrm{X}_{2} \rightarrow \mathrm{Y}_{1}$ & 0,392 & 4,577 & 0,000 & \\
\hline $\mathrm{X}_{1} \rightarrow \mathrm{Y}_{2}$ & 0,143 & 2,219 & 0,029 & Ha diterima \\
$\mathrm{X}_{2} \rightarrow \mathrm{Y}_{2}$ & 0,171 & 2,801 & 0,006 & $\begin{array}{c}\text { Ha diterima } \\
\text { Ha diterima }\end{array}$ \\
$\mathrm{Y}_{1} \rightarrow \mathrm{Y}_{2}$ & 0,677 & 10,198 & 0,000 & \\
\hline
\end{tabular}


$Y_{2}: \beta_{3} X_{1}+\beta_{4} X_{2}+\beta_{5} Y_{1}+e_{2}$

Keterangan :

$Y_{1} \quad$ : Komitmen afektif

$Y_{2}$ : Kinerja SDM

$X_{1}$ : Learning orientation

$\mathrm{X}_{2}$ : Modal sosial

$\beta \quad$ : Koefisien regresi

HASIL PENELITIAN DAN PEMBAHASAN Pengujian Hipotesis

Pengaruh Learning Orientation terhadap Komitmen Afektif

Hasil pengujian learning orientation terhadap komitmen afektif diperoleh nilai $t$ hitung sebesar 5,905 dengan nilai signifikansi sebesar 0,000 $<0,05$. Pada degree of freedom sebesar $94(n-k-1$; $97-2-1$ ), diperoleh nilai $t$ tabel sebesar 1,9855 , sehingga nilai $t$ hitung 5,905 > nilai $\mathrm{t}$ tabel 1,9855 . Hal ini menunjukkan terdapat pengaruh positif dan signifikan antara learning orientation terhadap komitmen afektif, sehingga pengujian mampu menerima hipotesis 1. Dengan demikian dugaan yang menyatakan learning orientation mempunyai pengaruh terhadap komitmen afektif terbukti atau dapat diterima.

\section{Pengaruh Modal Sosial terhadap Komitmen afektif}

Hasil pengujian modal sosial terhadap komitmen afektif diperoleh nilai $\mathrm{t}$ hitung sebesar 4,577 dengan nilai signifikansi sebesar 0,000 yang berarti lebih kecil dari tingkat kesalahan sebesar 0,05. Dengan hasil tersebut, maka nilai $t$ hitung sebesar 4,577 telah melebihi dari nilai $t$ tabel sebesar 1,9855. Dengan hasil tersebut maka modal sosial mempunyai pengaruh positif dan signifikan terhadap komitmen afektif. Hasil pengujian terebut dapat disimpulkan bahwa pengujian mampu menerima hipotesis kedua, sehingga dugaan yang menyatakan adanya pengaruh modal sosial terhadap komitmen afektif terbukti atau dapat diterima.

\section{Pengaruh Learning Orientation terhadap Kinerja SDM}

Hasil pengujian learning orientation terhadap kinerja SDM diperoleh nilai t hitung sebesar 2,219 dengan nilai signifikansi sebesar $0,006<0,05$. Pada degree of freedom sebesar $93(\mathrm{n}-\mathrm{k}-1 ; 97-3-$ 1), diperoleh nilai $t$ tabel sebesar 1,9858 , sehingga nilai t hitung sebesar 2,219 > nilai $t$ tabel sebesar 1,9858. Hal ini menunjukkan terdapat pengaruh positif dan signifikan antara learning orientation terhadap kinerja SDM. Hasil tersebut menunjukkan jika pengujian mampu menerima hipotesis ketiga, sehingga dugaan yang menyatakan adanya pengaruh positif antara learning orientation terhadap kinerja SDM dapat diterima.

\section{Pengaruh Modal Sosial terhadap Kinerja SDM}

Hasil pengujian modal sosial terhadap kinerja SDM, diperoleh nilai t hitung sebesar 2,801 dengan hasil signifikansi sebesar 0,006 yang berarti lebih kecil dari batas yang ditentukan sebesar 0,05. Dengan demikian nilai $\mathrm{t}$ hitung sebesar 2,801 > nilai $\mathrm{t}$ tabel $=$ 1,9858 yang berarti modal sosial mempunyai pengaruh positif dan signifikan terhadap kinerja SDM. Berdasarkan hasil pengujian menunjukkan bahwa pengujian tersebut mampu menerima hipotesis keempat, sehingga dugaan yang menyatakan adanya pengaruh modal sosial terhadap kinerja SDM terbukti atau dapat diterima.

\section{Pengaruh Komitmen Afektif terhadap Kinerja SDM}

Hasil pengujian komitmen afektif terhadap kinerja SDM diperoleh nilai t hitung sebesar 10,198 dengan nilai signifikansi sebesar 0,000. Hasil tersebut membuktikan jika nilai $\mathrm{t}$ hitung sebesar 10,198 telah melebihi dari nilai $t$ tabel sebesar 1,9858, yang berarti bahwa komitmen afektif mempunyai pengaruh positif dan signifikan terhadap kinerja SDM. Dengan demikian pengujian mampu menerima hipotesis 


\section{Uji Koefisien Determinasi}

Tabel 2. Koefisien Determinasi

\begin{tabular}{|l|c|l|l|}
\hline \multicolumn{1}{|c|}{ Variabel } & $\mathbf{R}$ & $\begin{array}{c}\mathbf{R} \\
\text { Square }\end{array}$ & $\begin{array}{l}\text { Adjusted } \\
\mathbf{R} \text { Square }\end{array}$ \\
\hline $\begin{array}{l}\text { Learning orientation } \\
\text { dan modal sodial } \\
\text { terhadap komitmen } \\
\text { afektif }\end{array}$ & 0,845 & 0,714 & 0,708 \\
\hline $\begin{array}{l}\text { Learning orientation, } \\
\text { modal sodial dan } \\
\text { komitmen afektif } \\
\text { terhadap kinerja SDM }\end{array}$ & 0,939 & 0,883 & 0,879 \\
\hline
\end{tabular}

kelima, sehingga dugaan yang menyatakan adanya pengaruh komitmen afektif terhadap kinerja SDM terbukti atau dapat diterima.

Nilai koefisien determinasi untuk pengaruh tidak langsung antara learning orientation dan modal sosial terhadap komitmen afektif diperoleh nilai Adjusted $R$ Square sebesar 0,708 , dapat diartikan bahwa komitmen afektif mampu dijelaskan oleh kedua variabel learning orientation dan modal sosial sebesar $70,8 \%$, sedangkan sisanya dijelaskan oleh variabel lain yang tidak diamati dalam penelitian ini.

Nilai koefisien determinasi pengaruh langsung antara learning orientation, modal sosial dan komitmen afektif secara bersama-sama terhadap kinerja SDM diperoleh sebesar 0,879 , yang berarti kinerja SDM mampu dijelaskan oleh ketiga variabel learning orientation, modal sosial dan komitmen afektif sebesar $87,9 \%$ sedangkan sisanya dijelaskan oleh variabel lain yang tidak diamati dalam penelitian ini.

\section{Uji Sobel Test}

\section{Pengaruh Learning Orientation terhadap} Kinerja SDM melalui Komitmen Afektif

Berdasarkan hasil pengujian sobel test diperoleh nilai Test Statisticnya sebesar 4,262 dengan two tailed probability diperoleh nilai signifikansi sebesar 0,000 yang berarti lebih kecil dari tingkat kesalahan sebesar 0,05 . Dengan hasil terebut maka dapat diartikan bahwa komitmen afektif mampu menjadi variabel intervening antara learning orientation terhadap kinerja SDM.

\section{Pengaruh Modal Sosial terhadap Kinerja SDM melalui Komitmen Afektif}

Hasil pengujian sobel test antara variabel modal sosial terhadap kinerja SDM melalui komitmen afektif, maka diperoleh nilai test statisticnya sebesar 3,021 dengan two tailed probability sebesar 0,003 yang berarti nilai tersebut masih di bawah batas yang ditentukan tingkat kesalahannya sebesar 0,05 . Penjelasan tersebut dapat diartikan bahwa komitmen afektif mampu menjadi variabel intervening antara modal sosial dengan kinerja SDM.

\section{Pembahasan}

\section{Pengaruh Learning Orientation terhadap Komitmen Afektif}

Learning orientation terbukti berpengaruh positif dan signifikan terhadap komitmen afektif, dapat diartikan bahwa dapat diartikan bahwa semakin tinggi learning orientation, seperti mengetahui hal-hal baru, melakukan training, umpan balik dan mengembangkan secara kontinue maka akan akan berdampak pada tingginya komitmen afektif karyawan. Hasil temuan ini memberikan indikasi bahwa karyawan akan mempunyai komitmen terhadap perusahaan jika ada perubahan terhadap peningkatan kebijakan system dalam proses pembelajaran yang dibuat pihak manajemen perusahaan yang 
melibatkan karyawan, sehingga karyawan akan lebih mengetahui tentang hal-hal yang baru, seperti produk baru, menambah skill, dan pengetahuan baru.

Perubahan sistem yang didukung dengan pembelajaran seperti mengadakan pelatihan bagi karyawan ini mencakup dasar pengetahuan yang dibutuhkan karyawan dalam penyelesaian pekerjaan. Dengan adanya pelatihan, maka karyawan akan termotivasi untuk memberikan dukungan kepada perusahaan karena dengan adanya pelatihan akan mampu meningkatkan ketrampilan karyawan.

Keterlibatankaryawan dalammemberikan pembelajaran tentu akan menambah gagasan-gagasan yang dimiliki karyawan sehingga apabila ada perubahan mampu ditindaklanjuti dengan baik oleh karyawan sebagai bentuk umpan balik. Untuk itulah diperlukan bagi pihak manajemen untuk terus menerus melakukan perubahan untuk mengembangkan kemampuan karyawan, sehingga dukungan karyawan terhadap perusahaan juga akan semakin tinggi.

Menurut Shanker (2013) menjelaskan bahwa terdapat korelasi kuat antara pembelajaran organisasi dan komitmen organisasi lebih khususnya pada komitmen afektif. Lebih lanjutWang (2007)menegaskan bahwa menciptakan dan mendorong budaya pembelajaran organisasi adalah mekanisme mendasar untuk memupuk komitmen organisasi. Hasil penelitian ini mendukung dengan hasil temuan penelitian Widodo (2010) bahwa orientasi belajar terbukti berpengaruh terhadap komitmen karyawan. Hasil temuan Song (2008) dalam Widodo (2010) juga menunjukkan bahwa orientasi pembelajaran berarti memastikan adanya sebuah perubahan positif baik dari peningkatan karyawan maupun organisasi.

\section{Pengaruh Modal Sosial terhadap Komitmen Afektif}

Hasil penelitian terbukti bahwa modal sosial mempunyai pengaruh positif dan signifikan terhadap komitmen afektif, dapat diartikan bahwa semakin tinggi modal sosial, seperti sharing informasi, interaksi dan tukar ide, optimalisasi pengetahuan dan kualitas jejaring, maka akan semakin meningkatkan komitmen afektif karyawan. Komitmen karyawan terhadap perusahaan akan meningkat jika karyawan mampu dalam berinteraksi guna memperoleh informasi sehingga akan tercapai tujuan bersama di perusahaan. Untuk itulah perlu adanya upaya dari pihak manajemen dalam serangkaian nilai-nilai atau normanorma informal yang dimiliki bersama diantara para karyawan, yaitu melalui kerja sama antar karyawan karena selain dapat menguntungkan karyawan sendiri dalam menciptakan lingkungan yang kondusif, juga menguntungkan perusahaan karena karyawan akan lebih maksimal dalam menyelesaikan pekerjaan.

Interaksi dapat berjalan dengan baik jika para karyawan dapat melakukan tukar menukar ide sesama rekan kerja dalam melakukan kerja sama. Dengan adanya tukar menukar ide tersebut, maka tentu akan semakin menambah tingginya dukungan dan ikatan yang kuat dari dalam diri para karyawan untuk berbuat sesuatu agar dapat menunjang keberhasilan perusahaan. Dengan adanya interaksi yang baik, maka dukungan dan ikatan antar karyawan akan berjalan dengan baik sehingga pihak manajemen harus mampu mengoptimalkan kemampuan karyawan secara maksimal. Dengan adanya komunikasi dan interaksi antar karyawan, maka akan memperkuat kerja sama yang lebih kuat dalam guna memberi solusi dalam memecahkan masalah karyawan.

Menurut teori yang dikemukakan Beyerlen et al (2005) bahwa modal sosial sebagai modal interaksi dan hubungan individu di tempat kerja, yang membuat orang bekerja sama dan meningkatkan komitmen seseorang. Penelitian ini mendukung hasil temuan Vincent Rousseau dan Caroline Aube (2010) bahwa modal sosial mempunyai pengaruh terhadap 
komitmen organisasi. Temuan ini juga didukung oleh Naseer dan Mahmod (2015), Atak \& Ramazan (2010), Ellinger et al, 2013) yang menunjukkan bahwa peningkatan sosial capital mempengaruhi komitmen afektif yang ada di dalam diri karyawan.

\section{Pengaruh Learning Orientation terhadap Kinerja SDM}

Hasil penelitian menunjukkan bahwa terdapat pengaruh positif dan signifikan antara learning orientation terhadap kinerja SDM, dapat diartikan bahwa semakin tinggi learning orientation, seperti mengetahui hal-hal baru, melakukan training, umpan balik dan mengembangkan secara kontinue maka akan semakin meningkaktan kinerja SDM. Temuan ini memberikan bukti bahwa dengan adanya perubahan terhadap kebijakan sistem yang dibuat pihak manajemen perusahaan, maka keterlibatan karyawan sangat diperlukan dalam proses pembelajaran guna mengetahui tentang halhal yang baru, sehingga hal itu akan mampu meningkatkan kinerja karyawan secara maksimal.

Orientasi pembelajaran sangat diperlukan bagi karyawan untuk mendukung perubahan sistem, yaitu dengan mengadakan pelatihan bagi karyawan guna mencakup dasar pengetahuan yang dimiliki karyawan dalam menunjang keberhasilan karyawan dalam menyelesaikan pekerjaan. Dengan adanya pelatihan, maka tentu akan berdampak pada tingginya ketrampilan karyawan dalam menyelesaikan pekerjaan sehingga kinerja yang dihasilkan juga akan optimal.

Kinerja karyawan dapat maksimal jika para karyawan mempunyai gagasangagasan sehingga apabila ada perubahan mampu ditindaklanjuti dengan baik oleh karyawan sebagai bentuk umpan balik. Untuk itulah diperlukan bagi pihak manajemen untuk terus menerus melakukan perubahan dengan mengembangkan kemampuan karyawan, sehingga kinerja yang dihasilkan akan semakin lebih baik.

Menurut Walled an Cummings (1997) dalam Widodo (2009) bahwa orientasi pembelajaran digunakan sebagai strategi pengendalian diri pada organisasi karena dapat membentuk ketrampilan dan kemampuan sumber daya manusia serta memiliki pengetahuan yang dapat meningkatkan kinerja. Hasil penelitian ini mendukung temuan Widodo (2009) dan Shafiq, Zia-ur-Rehman dan Rashid (2013) bahwa orientasi belajar mempunyai pengaruh terhadap kinerja sumber daya manusia dengan arah positif.

\section{Pengaruh Modal Sosial terhadap Kinerja SDM}

Modal sosial terbukti mempunyai pengaruh positif dan signifikan terhadap kinerja SDM, memberikan pengertian bahwa semakin tinggi modal sosial, seperti sharing informasi, interaksi dan tukar ide, optimalisasi pengetahuan dan kualitas jejaring maka akan semakin meningkatkan kinerja SDM. Hasil temuan ini memberikan indikasi bahwa kinerja karyawan dapat maksimal jika didukung dengan kemampuan karyawan dalam berinteraksi sesama karyawan. Untuk itulah perlu adanya upaya dari pihak manajemen melalui kerja sama antar karyawan karena selain dapat menguntungkan karyawan sendiri dalam menciptakan lingkungan yang kondusif, juga menguntungkan perusahaan karena karyawan akan lebih maksimal dalam menyelesaikan pekerjaan.

Interaksi dapat berjalan dengan baik jika para karyawan dapat melakukan tukar menukar ide sesama rekan kerja dalam melakukan kerja sama. Dengan adanya tukar menukar ide tersebut, tentu akan semakin menambah tingginya kinerja yang dihasilkan karyawan. Untuk itulah pihak manajemen harus mampu mengoptimalkan kemampuan karyawan secara maksimal sehingga kinerja yang dihasilkan juga akan optimal. Adanya komunikasi dan interaksi antar karyawan, tentu akan memberi solusi dalam memecahkan setiap masalah yang dihadapi karyawan dalam upaya pencapaian 
kinerja secara maksimal.

Menurut Akdere (2005) dalam Yosna (2013) menjelaskan bahwa eksistensi modal sosial karyawan menjadi penting karena mempengaruhi kinjerja karyawan yang pada gilirannya mempengaruhi kinerja organisasi. Penelitian ini sejalan dengan hasil temuan Stam dan Elfring (2008) dan Wahyuningrum (2013) yang menyatakan bahwa modal sosial memiliki pengaruh langsung terhadap kinerja karyawan. Hasil temuan Khoirini dan Kartika (2014) juga menunjukkan bahwa modal sosial mempunyai pengaruh positif terhadap kinerja karyawan.

\section{Pengaruh Komitmen Afektif terhadap Kinerja SDM}

Hasil penelitian terbukti bahwa komitmen afektif berpengaruh positif dan signifikan terhadap kinerja SDM, mempunyai arti bahwa semakin kuat komitmen afektif karyawan, seperti menghabiskan sisa karir, bangga terhadap organisasi, terikat dengan organisasi, terikat secara emosional, memiliki arti yang besar dan mempunyai rasa yang kuat terhadap organisasi maka akan semakin meningkatkan kinerja yang dihasilkan karyawan. Agar kinerja karyawan dapat meningkat, maka langkah yang perlu diperhatikan antara lain upaya dari karyawan untuk terus memaksimalkan kinerjanya yaitu dengan terus menghabiskan sisa karir utuk kemajuan perusahaan. Ada sikap dari karyawan untuk membanggakan organisasi ini kepada teman-teman atau lingkungan kerja lainnya sebagai suatu perusahaan yang baik untuk bekerja juga sangat diperlukan. Sikap yang tumbuh dalam diri karyawan terhadap permasalahan yang dihadapi perusahaan, artinya bahwa permasalahan yang ada dalam perusahaan seakan-akan pegawai merasakan bahwa permasalahan tersebut adalah permasalahan diri sendiri. Demi kemajuan perusahaan, maka karyawan harus merasa terikat dengan organisasi. Agar kinerja dapat optimal, maka karyawan harus mempunyai dukungan yang kuat dan berusaha untuk menumbuhkan rasa memiliki demi kemajuan organisasi. Ada sikap rasa khawatir kalau meninggalkan perusahaan, sehingga karyawan berusaha untuk bekerja lebih baik. Karyawan harus menumbuhkembangkan sikap berat untuk meninggalkan organisasi ini sekarang sekalipun menginginkannya.

Karyawan yang memiliki tingkat komitmen organisasi yang tinggi akan memiliki pandangan yang positif dan lebih berusaha berbuat yang terbaik demi kepentingan organisasi. Hal itu dapat dilihat dengan adanya keinginan dari karyawan tersebut untuk membantu organisasi, dan adanya anggapan bahwa organisasi tempat bekerja merupakan organisasi yang baik. Menurut Mowday et al. (1979) bahwa komitmen organisasi menunjukkan keyakinan dan dukungan yang kuat terhadap nilai dan sasaran (goal) yang ingin dicapai oleh organisasi, yaitu meningkatkan kinerja pegawai. Hasil penelitian ini mendukung temuan penelitian Armanu dan Mandayanti (2011), Syain (2013) dan Tobing (2009) bahwa komitmen afektif memiliki pengaruh terhadap kinerja karyawan.

\section{Pengaruh Langsung dan Tidak Langsung}

Hasil penelitian komitmen afektif mampu menjadi variabel intervening antara learning orientation terhadap kinerja SDM. Penjelasan tersebut dapat diartikan bahwa semakin tinggi learning orientation, maka semakin membuat karyawan mampu menyesuaikan diri antara sistem dengan lingkungan kerjanya sehingga akan meningkatkan komitmen afektif karyawan dalam pencapaian kinerja secara maksimal.

Komitmen afektif mampu menjadi variable intervening antara modal sosial terhadap kinerja SDM, dapat diartikan bahwa semakin tinggi modal sosial, maka akan terjalin hubungan interaksi dan jaringan yang baik dengan seluruh karyawan, sehingga mampu mendukung komitmen afektif karyawan dan hal itu tentunya akan berdampak pada tingginya kinerja karyawan 
secara maksimal

\section{SIMPULAN}

Berdasarkan penelitian yang telah dilakukan maka dapat diperoleh kesimpulan sebagai berikut :

Learning orientation terbukti berpengaruh positif dan signifikan terhadap komitmen afektif, dapat diartikan bahwa dapat diartikan bahwa semakin tinggi learning orientation, seperti mengetahui hal-hal baru, melakukan training, umpan balik dan mengembangkan secara kontinue maka akan akan berdampak pada tingginya komitmen afektif karyawan..

Modal sosial terbukti berpengaruh positif terhadap komitmen afektif, artinya semakin tinggi modal sosial, seperti sharing informasi, interaksi dan tukar ide, optimalisasi pengetahuan dan kualitas jejaring, maka akan semakin meningkatkan komitmen afektif karyawan..

Learning orientation terbukti berpengaruh positif terhadap kinerja SDM, artinya semakin tinggi learning orientation, seperti mengetahui hal-hal baru, melakukan training, umpan balik dan mengembangkan secara kontinue maka akan semakin meningkaktan kinerja SDM.

Modal sosial terbukti berpengaruh positif terhadap kinerja SDM, memberikan pengertian bahwa semakin tinggi modal sosial, seperti sharing informasi, interaksi dan tukar ide, optimalisasi pengetahuan dan kualitas jejaring maka akan semakin meningkatkan kinerja SDM.

Komitmen afektif terbukti berpengaruh positif terhadap kinerja SDM, artinya semakin kuat komitmen afektif karyawan, seperti menghabiskan sisa karir, bangga terhadap organisasi, terikat dengan organisasi, terikat secara emosional, memiliki arti yang besar dan mempunyai rasa yang kuat terhadap organisasi maka akan semakin meningkatkan kinerja yang dihasilkan karyawan.

Komitmen afektif mampu menjadi variabel intervening antara learning orientation terhadap kinerja SDM, artinya semakin tinggi learning orientation, maka akan semakin membuat karyawan mampu menyesuaikan diri antara sistem dengan lingkungan kerjanya sehingga akan meningkatkan komitmen afektif karyawan dalam pencapaian kinerja secara maksimal.

Komitmen afektif mampu menjadi variable intervening antara modal sosial terhadap kinerja SDM, dapat diartikan bahwa tinggi modal sosial, maka akan terjalin hubungan interaksi dan jaringan yang baik dengan seluruh karyawan, sehingga mampu mendukung komitmen afektif karyawan dan tentunya akan berdampak pada tingginya kinerja karyawan secara maksimal.

\section{Saran}

Atas dasar kesimpulan yang telah dikemukakan di atas, dapat diberikan beberapa saran dan diharapkan dapat berguna bagi kemajuan perusahaan. Adapun beberapa saran tersebut adalah :

Dalam pencapaian kinerja secara maksimal, maka sebaiknya pihak manajemen perusahaan perlu melakukan pembelajaran dengan para bawahannya dengan baik, seperti dengan melakukan pendidikan dan pelatihan sehingga bawahan dapat melakukan umpan balik apabila terjadi perubahan sistem karena karyawan akan mampu menyesuaikan diri dan berusaha untuk menindaklanjuti gagasan-gagasan yang disampaikan pimpinan.

Dalam meningkatkan kinerja SDM, maka terdapat faktor yang menjadi perhatian perusahaan terkait dengan modal sosial , diantaranya kemampuan pihak manajemen dalam mengoptimalkan pengetahuan karyawan, yaitu dengan memberikan pendidikan dan pelatihan sehingga akan semakin meningkatkan ketrampilan dan pengetahuan karyawan.

Hasil tanggapan terlemah pada komitmen afektif yaitu pada indikator memiliki arti yang besar, sehingga pihak manajemen perlu memberikan dukungan yang tinggi kepada karyawannya agar perusahaan memiliki arti tersendiri, seperti dengan mengajak 
bawahannya untuk berpikir memajukan perusahaan melalui meeting dalam membahas masalah yang terjadi pada perusahaan

\section{Keterbatasan Penelitian}

Berdasarkan penelitian yang telah dilakukan, maka keterbatasan dalam penelitian ini sebagai berikut:

Variabel penelitian ini hanya terbatas pada 2 variabel saja, yaitu learning orientation dan modal sosial sehingga kurang memenuhi kondisi nyata terhadap permasalahan yang terjadi

Teknik pengumpulan data yang dipakai dalam penelitian ini hanya menggunakan kuesioner sehingga kesimpulan yang dapat diambil hanya berdasarkan pada data yang dikumpulkan melalui kuesioner tersebut. Data yang dianalisis merupakan persepsi jawaban responden yang dapat menimbulkan masalah jika jawaban responden tidak sesuai dengan keadaan yang sesungguhnya.

\section{Agenda Penelitian Mendatang}

Pada penelitian selanjutnya sebaiknya perlu menambah variabel penelitian, seperti human capital, motivasi spiritual, knowledge sharing agar dapat meningkatkan peneitian yang lebih baik lagi.

Pada penelitian selanjutnya sebaik ditambah dengan teknik wawancara sehingga akan lebih memperkuat keakuratan data.

\section{DAFTAR PUSTAKA}

Andrawina, Luciana, dkk. (2008). Hubungan Antara Knowledge Sharing Capability, Absorptive Capacity Dan Mekanisme

Formal: Studi Kasus Industri Teknologi Informasi Dan Komunikasi Di Indonesia. Jurnal teknik industry, 10 (2) : 158-170.

Armanu Fatchur Rohman dan Mandayanti. (2011). Pengaruh Pemberdayaan Psikologi Dan Komitmen Afektif Terhadap Kepuasan Kerja Dan Kinerja Pegawai. Jurnal Aplikasi manajemen, 1 (1), ISSN :1693-5341

Christa, Usup Riassy. (2013). Peran Human Capital Dan Structural Capital Dalam Meningkatkan Kinerja Organisasi (Suatu Kajian Konseptual). Jurnal Sains Manajemen, 1 (1), ISSN : 2302-1411

Coleman, J. (2005). Social Capital in the Creation of Human Capital. Cambridge Mass: Harvard University Press.

Dessler, Gary. (2009). Manajeman Sumber Daya Manusia, Jakarta : Prenhallindo.

Fukuyama F. (1999). "Social Capital and the Global Economy". Foreign Affairs, 74 (5) : 89 - 97.

Greenberg, J., \& Baron, R. (2003). Behavior in Organization (fivth edition). New Jersey : Prentice Hall.

Handoko, T. Hani. (2012). Organisasi Perusahaan, Teori, Struktur dan Perilaku, Yogyakarta : BPFE.

Husammi, Endo W. (2008). Pengaruh Komitmen Afektif Dan Human Capital Terhadap Kinerja SDM Dengan Knowledge Sharing Sebagai Variabel Intervening. Jurnal Ekobis, 2 (1).

Indriasari, Ika. (2013). Pengaruh Komitmen Afektif, Persepsi Saling Ketergantungan Tugas Dan Keterlibatan Kerja Terhadap Sharing Pengetahuan Pada Auditor. Jurnal Dinamika Ekonomi dan Bisnis, 10 (2).

Makrufah, Siti. (2011). Pengaruh Budaya, Pembelajaran Organisasi Terhadap Kinerja Karyawan Hotel Bumi Surabaya. Jurnal Akuntansi, Manajemen Bisnis dan Sektor publik (JAMBSP). ISSN 1829-9857.

Mangkunegara, A.A. Anwar Prabu. (2012). Manajemen Sumber Daya Manusia, Rineka Cipta : Jakarta. 
Mas'ud, Fuad. (2004). Survai Diagnosis Organisasional : Konsep \& Aplikasi, Badan Penerbit UNDIP : Semarang

Mathis \& Jackson, Fred N. (2006). Administration of Public Education Fourth Edition : A Source Book for The Leadership and Management of Education Instituion, Harper \& Row Publisher : New York.

Mowday, R.T., Steers, R.M. \& Porter, L.W. (1979). The Measurement of organizational commitment. Journal of Vocational Behavior, $14: 224-227$.

Muchiri, (2012). Komitmen Afektif Dalam Organisasi Yang Dipengaruhi Knowledge Sharing Dan Kinerja Organisasi. Jurnal Manajemen Dan Kewirausahaan. 14 (2) : 109 - 117.

Putnam R. (1995). Bowling Alone: America's Declining Social Capital. Journal of Democracy.

Robbins, Stephen P dan Judge. (2007). Perilaku Organisasi : Konsep - Kontroversi - Aplikasi Jilid 2. PT. Prehallindo : Jakarta.

Rachmawati, D., F. Wulani, dan C. E. Susilowati. (2014). Intellectual Capital dan Kinerja Bisnis: Studi Empiris pada Industri di Indonesia. Seminar Internasional Management and Research Conference, Sanur Beach Bali Hotel.

Rachmawati, D., dan F. Wulani. (2014). Human Capital dan Kinerja Dareah: Studi Kasus di Jawa Timur. Penelitian APTIK : 1-73.

Riduwan. (2009). Skala Pengukuran Variabel-Variabel Penelitian. Alfabeta : Bandung.

Ressya, Rezakhi. (2014). Pengaruh Pembelajaran Organisasi, Terhadap Kinerja Dengan Kompetensi Sebagai Mediasi. Jurnal Manajemen, 1 (1).

Sabir, M. S., Sohail, A., \& Khan, M. A. (2011). Impact of Leadership Style on Organization Commitment : In A Mediating Role of Employee Values. Journal of Economics and Behavioral Studies, 3 (2) : 145-152.

Schwandt, D.R., and Marquardt, M.J. (2000). Organizational learning: From worldclass theories to global best practices. St. Lucie Press.

Shafiq, M., Zia-ur-Rehman, D., \& Rashid, M. (2013). Impact of Compensation, Training and Development and Supervisory Support on Organizational Commitment. Compensation \& Benefits Review, 45(5), : 278-285.

Shanker, M. (2013). Organizational Commitment and Employees Intention to Stay in Indian Companies: Factor Analytical Approach. Journal of Psychosocial Research, 8(2) : 199208.

Umar, Husein. (2012). Metodologi Penelitian : Aplikasi dalam Pemasaran, PT. Gramedia Pustaka Utama : Jakarta.

Uniati, Monica Ida. (2014). Learning Organization, Komitmen Pada Organisasi, Kepuasan Kerja, Efektivitas Penerapan Sistem ISO Dan Dampaknya Terhadap Kinerja Organisasi. Jurnal Manajemen Pemasaran, 8 (1).

Vincent Rousseau and Caroline Aube. (2010). Social Support at Work and AffectiveCommitment to the Organization: The Moderating Effect of Job ResourceAdequacy and Ambient Conditions. The Journal of Social Psychology, 150 (4) : 321-340.

Widjajanti, Kesi dan Widodo. (2014). Pengembangan Inovasi Organisasi Berbasis Human Capital, Sharing Knowledge Sharing Dan Pembebelajaran Organisasi. Ekobis, 15 (1) : 86-101.

Widodo. (2009). Model Pengembangan Human Capital Dalam Konteks Modal Social. Benefit Jurnal Manajemen dan Bisnis, 13 (2) : 88-106. 